\title{
Alberto Guillén, el Buscador de sí Mismo
}

\begin{abstract}
Arequipa
CIUDAD ilustre enclavada en lá cordillera del Perú, recogida, como fortaleza de la teja serrana y de la cal y el canto de nuestras mansiones provincianas, en uno de los repechos de los Andes. Arequipa, coronada por el triángulo del Misti. Poblada de caserones de Colonia y de casitas iguales. Elevada en las torres de sus iglesias en las cuales apunta el típico barroco o sonrie a veces la gracia implorante, rezante, de la ojiva. Provincia. Alta para los sueños y casi remansada para los heroísmos. Provincia en la cual hemos de masticar - recuerde Guillén de su asno subjetivo- la paciencia de la alfalfa y hemos de comer de la abundancia del laurel cuando nuestro Marsias vaya para Pegaso... Provincia de la cual hemos de sacar, sin embargo, el brazo fuerte y el corazón precioso para triunfar en la ciudad. Arequipa y alli la nacencia de
\end{abstract}

\section{Alberto Guillén}

De casa provinciana. La madre acendrada de ternuras y de intuiciones. El padre, mílite y gallardo como a la edad de Garcilaso, con el noble pecho bajo áureo bordado del traje de parada. Guillén: un tipo dulce y fuerte - bajo el corazón recio el suspiro celeste. Vuelo de metáforas. Ensayo de orgullo para construir la propia troquelación. Desdén hondo de si mismo, por lo que de si propio ha de reclamar para ese continuo superarse. Cuartillas desarregla- 
das en un orden de ascenso como en el grito diversificado de la oda. Un gran amor por la vida y un deseo perpetuo de matar a la muerte. Sus cuatro hermanitas - morenas y blancas-, alegría morena del trigal y florecer blanco de los panes pascuales.

\section{Laureles}

Uno de los primeros libros de Alberto Guillén lleva este título casi olimpico: Laureles. Precede a los tres poemas de concurso y de antología (¿ paradoja?), una desaprensiva historia de sus propios triunfos. Cómo salió el provinciano de la provincia. Cómo tembló su corazón de pajarillo con los primeros aplausos. Cóno le arrebataron el primer lauro y la hoja del primer poema. Cómo le miraban, recelosos, los tribunales oficiales. Cómo estuvo de trepidante el teatrillo ante su revelación inicial. $Y$ su madre de ternezas y de emociones. $\mathrm{Y}$ la varonil postura del padre y el revoleo de santidad $\mathrm{y}$ amor de las cuatro figuras fraternas.

$Y$ hay que viajar. Hacia la vastedad marina. Por la anchura de cristales quebrados $y$ de gaviotas tendidas sin fatiga. Escuchando la música de los caracoles. Hacia el Callao y hacia la Lima de sedantes y de inquietudes, "ciudad de reinas más que de reyes", hacia la Lima del pensamiento y las finuras, del poema y del beso, del vuelo y el reposo.

Alli, nuevo laurel. Fuga, después, hacia la tierra de los quetzales, llevándose los recuerdos de Isabel y afirmada ya, en la lealtad del conocimiento, la silueta "dominadora y serena" de Leguía. Y el tercer lauro, ya doneñado y de costumbre.

Laureles se llama uno de los primeros libros de Guillén. Áletea en él, con vigores de redescubrimiento, la realidad o el espejismo, el dolor o el gozo de la gloria. Su moceril espiritu creyó en los laureles, pese a la actitud de quienes desdeñarían esas ramas mutiladas y perdurables, aun cuando buscasen la carne salada de la aceituna, el fruto de la oliva, el huevo de la gloria...

\section{Antiguo y nuevo}

Guillén es hombre de memoria. De recuerdos y de estudios Aún en su estanteria transeúnte se alinean los clásicos y en ella la resis- 
tencia del pino opone su dura coherencia al avance filtrador de la polilla. Marcha también, y con pasos seguros, hacia el mañana. Todos somos, Alberto Guillén, de hoy. Fuimos de ayer y seremos de mañana. Generaciones niñas, por ley de su propia física, se sienten dueñas de todo el campo. Ya caminarán. $\mathrm{Y}$ entonces sobre el rizo en otro tiempo fresco caerá, si fueron hombres, la nevazón femenina de la estrella. Si supieron vencer a la noche con su varonilidad de dia. $\mathrm{Y}$ entonces interrogarán por nosotros y sabrán, con el asombro de encontrarnọs, que ya seguimos para el futuro.

Completo el primer libro de Guillén. Egloga nueva, madrigal, épica. Poeta de provincia, está más cerca del marco floral y de la extensión del campo. Como yo lo estuve, en mis ancestros, en los Miraflores y en los Catiglatas, en los Ficoas y en los Atochas. Como yo lo estuve, en familiares raíces, en el solar español de los Quisapinchas... y como yo, más tarde, dormí mi gran sueño en El Sueño y quise que mi grito fuera recogido por la roca desafiante de los Tilulunes.

Pero Guillén en su égloga primera no es contemplador pastoril como Teócrito, ni mítico bordador de figuraciones de pastores como Bion y Mosco. Ni le gusta, tampoco, la descansada vida de Fray Luis, reminiscencia de la quinta agustiniana. Es voz de nueva égloga. Hombre citadino en el campo. Evocación de antiguos dominios. Pastor de flores y de frutos. Cuadros breves, breves, como lo quisieron los clásicos para sus idilios. Panoramas, huertos, sendas, signos, panteísmo, plática, armonía, Y el envío a Virgilio, "un puñado de perfume de rosas". Envío luengo y de vencer milenios. Antiguo y nuevo.

Luz Elena es el sujeto de su madrigal frustrado. $\mathrm{Y}$. eso que Guillén no arroja su "corazón de hombre" ante "cualquier María". ¿Frustrado por qué? Guillén es pobre. Ofrécele sólo, como mantel, el verde de la grama y allí, como pan, sólo su corazón amante. Pero las novias se alimentan mejor de alcachofas.

La oda a Bolívar, canto épico, quebrado en las modulaciones det hemistiquio del verso de Alejandro, es coreado por una docena de poetas. $\mathrm{Y}$ con el multilocuo Chocano, el alto Gálvez y el simbólico Eguren, quienes le disciernen el premio metálico y reverdeante. Oro y laurel. Pan y floresta. Pero el amor no viene, no ha venido. En vano se pregunta Guillén si ésta, si estotra que han pasado indife4 
rentes o con sonrisa, estarán en rumbo hacia el país de sus intimidades. Mas el jirón de épica, sonoro y silencioso, de imágenes interiores y de rápidas descripciones, ha surgido. Guillén ya sabe que puede cantar a todos los motivos. Al campo virgilista, a la mujer y al héroe.

\section{Diógenes y el corazón payaso}

Guillén nos ha contado que su fortuna quiso darle la dádiva de la risa. Su corazón rió. Por eso, al querer exprimirse la glándula de las lágrimas, el corazón se retorcía en un esfuerzo heroico de volatinero. Quién supiera la fortaleza de su corazón, Alberto Guillén. La de estrangular el hipo aun cuando todavia se llore.

Guillén, por humorismo, ha querido verse a veces con las orejas filosóficas del asno. Pero de ellas le han salido alas. Su ruiseñor es, además, de los que no quieren callar. $\mathrm{Y}$ observador por esencia, tuvo también, desde el comienzo, su linterna.

Así alumbrado, exploró, ascendió, viajó, llegó. Todavia camina. Limpia la luna de su lámpara cuarido le han empañado las brumas del decurso. Y su corazón es todavía saltarín. Ensaya nuevas piruetas másculas.

\section{La imitación de muestro señor yo}

Pájaro. Estrella. Mariposa. Mujer. Signos del horóscopo. También a los griegos se les vino su panteísmo de las viejas teogonías orientales. Y queriendo hallarse en todo, dieron al fin en la escultura sola y alta que, identificándoles, había de separarles también de sus dioses. Así utilizaron de sus mármoles con la heredada virtud de los pelasgós y el temblor antiguo de los ritos apagados o casi olvidados. Asi queremos buscarnos en los motivos exteriores y damos, al fin, en nosotros mismos, como que fuéramos el espejo y la linterna, la onda y la vibración, el viento y la antena. Una tenaz alegría de camino es la que repasa y salta y asciende y vuelve y sigue $\mathrm{y}$ sube en la imitación de muestro señor yo. Pueril ejercicio pensar en el Kempis por la semejanza del titular. Ni tampoco en el Narciso inclinado en adorativa inmovilidad sobre el cristal estático. Para ese rostro de renovadas inquietudes; el lago se quebraria en angustias 
concéntricas, pues no la belleza dueña de su puro contorno, casi femenina, casi inmaculada, seria la de una ponderosa autocontemplación, ya para siempre el retrato amoroso que ningún otro reflejo pudiera devolver y fuera después nada más que la flor, secada la luna acuática, en cambio de simbólica y perfecta soledad. Ni menos la otra imitación, crucificada y ascética, dolorida por la virtud de centenares, humilde de renuncia, cilicio para el retoño del día resurrecto. Canta aquí un orgullo nuevo, joven, potente. No desafiante y efímero como el de quien anduviera con similores jupiterinos, hechos nada más que del brio de una jubilosa mañana. Prestancia de vencer aun cuando va de vencida, dolor que se aguza en la flecha del grito, flecha que se quiebra a sí misma, que se mutila adrede con la lima oficiosa de la ironía. Y quizá por esto no nos es dado sonreir de la autodivinización de Guillén, tan humano y, no obstante sus hiperbólicos cantos, tan parco. ¿ Parco? Justamente. No hay término entre la desesperación inmensurable del propósito wertheriano y el desdén fáustico doctorado y maduro, malicioso y conquistador, dueño de sí y desprendido de si propio, confiante y distante, central y desorbitado. La sima del suicidio o la posesión maravillosa, el dominio, la sumersión. La cordura de Guillén brota de la inadvertida flor de la antítesis. El jugo de sus más audaces paradojas y el humanismo tranquilo del descenso sonriente que trata de ensayar cuando ha buscado el ágil contracielo de sus saltos más elevados.

El mundo zoológico le ofrece instantes de comparación breve con el de quienes poseemos la virtud de la palabra. La inteligencia ilumina el rápido fugar de las parábolas y en ellas despiértase y exáltase una felicidad hipotética o real, pero que lo es quizá sólo frente al espejo que se ha detenido para copiarlas. $Y$ vuelve de sus altos viajares a la tierra gravitante y rugosa que nos sustenta $y$ parece indolente a nuestra marcha. Si perdurara la morosa, la clamorosa, la admirativa autocontemplación, dudariamos tal vez del nuevo narcisista, éste si de viril egolatría, que busca, con obstinada prisa, para remirarse y elogiarse, todos los espejos y todas las lunas. Pero aquí hay un vuelo de gracia, un instinto superior do incautarse de las luces de la vida, un afán curioso y consciente de volverse, si no imagen girovaga y difundida, ojo que mira hacia todas las latitudes, aun cuando fuera para recogerse, pupila millonaria, irisada de descubrimiento, sapiente de ver, paisaje de sí. No de otro 
modo parécenos grito múltiple y palabra sola y una, la imitación de nuestro señor yo.

No creo yo que el de Guillén sea placer inmune. Hay que seguirle en su esencia que se rezuma y se reabsorbe vena adentro y que, por eso, no salta en la lágrima. Imposible anotar en sus anotaciones; como hechas de propósito en una magisterial brevedad, modelos no de lo trunco, sino de lo sintético. Epitafios, epigramas siglo XX. El que huye del dolor que le busca el corazón, subiéndose sobre su alma como quien huyese de un perrillo saltando a una silla; el que conoce que aquella ilusa lloraba por no encontrarse las alas en las axilas; el que cree que el antidiós es. Sancho; el que advierte que los gusanos han ganado la batalla; el que no duda de que el vuelo es ciego, pensando en la escultura de Samotracia, no está en el placer inmune. Al paso de cada frase concisa de su imitación, le sabemos insatisfecho, aun cuando no se prodigue en la copiosidad de la quejumbre: "Hombre soy y no me basta. En cambio no sé de ningún asno que aspirara a caballo", o "Me duele tener mis cumbres dominadas". Así, por el tránsito de su libro nos es dado contemplar como a quien hostigado de la compañia vana, quisiera al término, debiera o se obligara a un regreso frente a la presencia duplicadora del yo, frente al espejo que es el amigo quieto y luminoso. Por eso ha debido sonreir al descubrimiento de la nueva y orgullosa búsqueda diogenesca. No hay un hombre. Es inútil la persecutora lámpara por entre la tiniebla matizada de luciérnagas. Y en medio de una parpadeante escuadra de cocuyos, Diógenes se ha encontrado a si mismo en su espejo de bolsillo.

\section{Deucalion}

El "yo" regresa en el sonetario ágil de Deucalión. Cuán lejos se borra y se descompone, para este canto actual, la sabia y miniada y lenta devoción petrarquista. Ni el Dante, violenta y sin embargo profundamente evocado en la página liminar de Ventura, estaria a tono con el temblor de esas catorce columnas, inacabadas en su fin, terminadas en su prịncipio, admirativas en su misma suspensión, definitivas en sus indefiniciones. No en medio del camino de la vida; ni siquiera, pensamos, tal como lo intuye la deliciosa cuartilla de García Calderón, en la morada en donde el amor se encumbra des- 
pojado de celos y amarguras. Ni Virgilios puros y videntes, ni florentinos que supieran salvar de las ardencias del Purgatorio, sin que se quemara el laurel, henchidos de conciencia, en marcha hacia los campos ignorados en donde lo que no se alcanzó brilla como nunca compensador e infinito, porque lo que ya no se pide es sobrehumanamente más inmenso que lo humano inefable que no se pudo recibir. Ni Beatrices dantescas, ni terrenas Lauras deshumanizadas en fuerza de los lirios avignonenses que no permitieron mirarlas como a criaturas, pero ni Margaritas materiales asesoradas por Mefistófeles con traza de Celestinas...

De la página de Ventura, divina por la ruta de quien buscó el cielo y humana por el acre regusto de los círculos contemporáneos, ya que no propiamente dantescos, es igual la salida a los sonetos de Guillén en los cuales el yo tremendo y obstinado, nombre propio y desenfadada y alacre alusión moceril, marcha al encuentro de sí mismo y se crucifica o se abraza, se da y se repele y cae, al fin, fatigado que no vencido, para buscar en la tierra mater el sabor de los labios eternos que no son otros que los suyos. Cantilena de eternidad que no se podría, francamente, arrancar de la prematura arborescencia de los veinte años, de no afirmarse en la verdadera siembra de Deucalión. Risa, risa y dolor. Fortaleza de David. Alegría urgida como la de quien supiera que ha de acabarse muy pronto el júbilo proteico, hecho de más aristas como de pararrayos, cuanto más arrecia la tempestad eléctrica que ha de atraerse con imanes locos para que se estremezca la torre de las esperanzas y sienta el goce de verticalizar a los zig-zags y llevarlos a una terca fundición con la tierra. Potque aquí es de otra suerte ese canto en el cual probamos a los poetas juveniles, el de saberse pasajeros con la primavera que llevan, el de pedir para la fiesta de hoy todos los elixires, pues que bien puede caer escarcha verdadera sobre las sienes palpitantes $y$ doradas otrora. Pero los elixires atosigaron a los gentiles jóvenes dionisíacos...

Guillén no desespera: "Apura-me dicen las horas-la sepultura-bosteza en todas las auroras;-apura, ya las sonoras-alas te urgen a la altura ; - apura, y la amargura - te espera oculta en lo que adoras.-Pero yo sigo, lento el paso-bebiendo a sorbos en mi vasomi vida en calma-porque yo sé que bajo mis sienes-va mi venganza:-Tienes-miedo a los muertos, Alma ?" Mas no siempre he$4 \star$ 
mos de seguirle en igual prueba voluntariosa. Lo contrario sería pedir al hombre actitud digna tan sólo de los inmobles físicos. Contradicción es la vida y ni la suerte de los árboles es la de ascender verticalmente, acendrando savia con lentitud y dándose en la flor siempre renovada y preciosa. Duda y voluntad, tristeza de pasar, despojándose, como la sierpe, de la piel en primavera; fatiga, sed como Agar, en el desierto, "pero que no te vean llorar..."; peregrinaje, como el de Ashaverus; nueva estatuaria de Lot que vuelve los ojos al pasado para verse muerto; máscara sobre el gésto trágico; nihilismo a veces; señalamiento estrellado para sus huellas fértiles; elegia y anacreóntica, ara y cruz, tienda y canino, fantasmas y cuerpos, bordones y arrogancias, jalones y recomienzos, sabor de cenizas y conciencia de perduración, paraíso adánico y caida de ángel, como la de Abadonna, gloria y vacío, anhelo y saciedad...

Pero Deucalión no sabe verter sutil melancolía, ni regresa, tampoco, en la hipérbole de las negaciones, después de que nos ha exaltado, llevándonos en el contraste de lo perecedero que puede, no obstante, iluminar y amar y casi durar... El poeta grita su nombre, vocalizándolo, elevándolo, claro y puro, sin rubores, como si fuese el de un Adán de otro Paraíso en el cual no existiera la hoja sastreril de la modestia falsa. Grita su nombre, seguro de la amistosa devolución del eco, del silencio elevado de las estrellas, de la paciencia aristotélica de las esferas. Memoria de otras vidas para su canto rejuvenecido. Heroísmo de existir que pasa de cara a la muerte, a esta asechanza perpetua que ha de pedirnos o la espera lenta $y$ angustiada del Eclesiastés o la templanza joven de Deucalión o el laboratorio de buscarnos en lo que se desintegra lo perenne, lanzando nuestras palabras a los vientos, por si ellas pudieran fijarse en las nubes futuristas, para una constelación que no hubiera brotado de nuestro silencio ni de nuestro desencanto.

\section{El corazón infante}

Novelina. Cuento salado. Deseo que se ha traido desde la nifiez de la sierra para que reviente en la adolescencia de la costa. Corazón que frutece de pronto, sin rama, junto al cantil, y que se queda luego $\sin$ ser exprimido, gustado... Pero para los banquetes 
frugales o para la cena devoradora, será la poma intacta y temblorosa. Guillén ha movido los personajes en esta su narración casi poemática y con una suave y conmovida displicencia -otra vez su paradoja - ha sabido recontarnos la verdad de que en el fondo de todas las páginas hay un cierto ápice autobiográfico. "Y él, que nunca descubrió el corazón ni a las mujeres -a las mujeres menos que a los honibres- mostró el corazón desnudo. Descubrió el corazón infante que todos llevan en el pecho de hombres..." No sé qué desolación de la Dido virgiliana flota en esa roca, frente a ese mar, junto a ese sonetillo que pretendió reflejarlos y que no imitó nada más - ¿nada más?-- que el golpeteo de oleaje de su corazón grumete. El mismo la llamaba Dido. El cuento fué menos extenso que è de Eneas y el dominio no llegó ni a la primicia. Mas, cerca del libro rojo, cerca del maldito libro de Nietzsche, se tendian los cauces para no volver, profundos, interrogantes. $\mathrm{Y}$ el cuento no se concluye. La dama de la sortija negra se queda en un pueril y misterioso viaje de bodas... Acaso el clasicismo nuevo sea el de dejar a Dido oscilante sin muerte y sin palabra cierta en el pendulario de la vida. ¿Que a Prometeo le devoraron las entrañas? Nueva tragedia la del cuervo que no llega, mientras se desprende la roca para convertirse en una barca errabunda.

\section{Los epigramas}

Guillén, nuevo y antiguo, ha escrito un libro de epigramas. No lo satírico en el concepto de Marcial, ni el aprecio en el cual tenían los latinos a ese género breve e ingenioso. El epigrama, como la abeja griega; está henchido del dulzor de la miel y lleva la punzadora gracia. Elabora, en la cera del colmenar de las ideas y de los senttimientos, figuras ligeras y mínimas. $O$ con estilete ingenioso escribe su letra alada... Epi. Grama.

Estas abejas de Guillén revuelan, irónica, tenuemente, en torno de las mujeres y acuerdan su viaje con el pensamiento de los hombres. "No es para doncellas-ni para donceles-es libro para hombres-y para mujeres", dice en su prólogo de cuarteta prontísima. Hay en esos epigramas una alentadora brisa contra-romántica que no lo es tanto como para impedir que, en alguna vez, oree tenuemente sobre la casi figura del madrigal. Ira filosofia se exprime clarísima 
y en jugos de gustarse sin ninguna preparación sibarita. No hay, ni por asomo, en estos epigramas eróticos, el atisbo de un Petronio, y si más bien se acusan, en raro momento, de un lejano toque anacreóntico, sólo el impulso guillenista los guía y acaba. Los hay de dramática síntesis, como el marcado con el número cuarenta:- "Horas: las 5-Tema:-Un amorío-de cinema-Corazón : da un brinco -y arrójate al río--amor que no quema-te deja vacio". O también algunos que ensayan algo como un antimadrigal: "Hay que loar a la rosa-dice Anacreonte-Loemos también la hermosa-rabia del saltamonte-que se olvida de la rosa-por saltar el horizonte..."

Copiaríamos aqui todo el centenar de epigramas. No preceptos para amar, como los de Ovidio, sino más bien datos de amador que se ríe del amor e inicia, jugando; escarceos provocativos.

\section{Guillén andariego, antologista}

Guillén andariego. Pero bajo el pliegue de la americana del turista o de la bordadura de la casaca del diplomático, el corazón infante, el corazón ligero o el corazón de fortaleza. $Y$ siempre disparándose las saetas de sus jubilosas metáforas, de sus descubrimientos, de sus afirmaciones.

En Santiago de Chile, accediendo a un reclamo de Nascimento, preparó una breve Antología peruana. Flores escogidas, florilegio, en los dos nombres de griega rama... Guillén no tenía, entonces, el abundante material de la jardinería de su patria, mas en el revuelto bullicio melódico de sus maletas, iban algunas hojas viajeras y selectas. Las puso en orden lírico, sin metodización criticista y asi nació la breve Antología. Alli estắn hasta cincuenta poetas, iniciándose con la elegía de García Calderón y cerrándose el desfile con "las anotaciones aguijadas de novedad" de Julio del Prado. Son voces mélicas casi todas y antes de que se insinúen en el verso, el antologista las ha comprendido en tres, en cuatro lineas que son, también, un poema, un anuncio, un preludio. Guillén ha declarado, en muchas veces, cómo quiso apartarse de la posición del crítico. No lo será en el sentido académico, ni acaso en el que busca construcción tenovada sobre el edificio de los libros ajenos, pero lo es, siquiera en dosis de impresionismo poético, cuando contempla, cuando advierte. Ya no es de ahora la verdad de que los juicios 
originales suelen entrañar verdaderas creaciones y que un mismo libro no ha de revelarse idéntico ante objetivos que obedezcan a la diversidad luminica de distintos observadores. $Y$ ya podemos resolver, sin mucha prisa, acerca del juicio del poeta en el cual se cumplirá, con mayor seguridad, la propuesta enunciada. Guillén define a sus poetas, en veinte, en treinta palabras cantantes, como cuando dice de si mismo: "Síntesis ante todo. Esqueleto de poema. E'sencia de jugos vitales. Poesía mondada llena de puntas como empinada montaña. Humorismo y ternura trenzados en el mismo poncho de criolla altanería..."

\section{La poesia vernacular}

"Alberto Guillén está madurando en ñiño", ha escrito recientemente César A. Rodríguez en el preludio de su Leyenda patria, diferenciando los valores, ya no temporales sino más bien anímicos, de la edad primeriza y de la vejez. Ser niño. Volver a ver las cosas como si se las contemplara por la primera vez. Descubrirlas, aun cuando la fuerza antecedente no pueda ser evitada, pero advocándola no como experiencia precisa, sino más bien como retentiva universal, quizá más clara y propia en los ojos del niño, limpios. de la superposición de los paisajes, del cansancio itineral. Lo niño de Guillén está floreciendo ahora en las páginas de su Arequipa.

La misma originalidad acaso no sea, en término único, sino la disposición niña para ver las cosas, para comprenderlas y poder sacar de aquellas el cuociente virgíneo que no sospecharon tantos otros contempladores pertinaces o curiosos, pero carentes de la juventud receptora, que quiere o sabe descubrir. De regreso a sus andanzas, Guillén arriba a un conocimiento profundo de Arequipa. Porque el suyo no es - a lo menos por los poemas que conozco del libro en flor- un apunte poético físico, geográfico si se quiere, susceptible de nuevas expresiones, pero trazado por el motivo más o menos perenne, sobre modelo que se dijera desnudo y fácil para cuantos se llegasen a él. $\mathrm{Ni}$ es la penetración en el alma del paisaje, con sequedad azoriniana o vehemencia de elogiante filial - lo subjetivo del paisaje-, sino más bien, y aquí el gran acierto niño de Guillén, la evocación de las figuras, el pulso firmisimo para descubrir los caracteres fisonómicos, de tal manera que de lo particular e 
individual de todos esos tipos entrañables, su poema sin oratoria ni arabesco, consigue, de simple y vital modo, animar y reavivar los personajes arequipeños que fueran el Abuelito, el santero don Julián, la escena hogareña ante el chiquillo resentido, la madre y las hermanitas, y en otro plano, en el de la colectividad más difundida y simbólica, hasta las visiones históricas como la de Pizarro, resurrecta en aquel poema que ha merecido múltiples traducciones y que ha de quedarse, de seguro, como uno de los más completos signos de ta literatura peruana, americana. Todavia es, aun cuando rara figura de nuestras ciudades, aparición tradicional y laboriosa, la del-imaginero, como el don Julián de Arequipa, constructor de Cristos doloridos o de santos sonrosados en el tronco de madera que va puliéndose en facciones y en gestos, como si saliese del torno, en unas veces genial y en otras ya casi mecánico, por lo repetido, de sus manos. $\mathrm{Y}$ no que pensemos en el Pampite iluminado de la colonia quiteña, sino que nos refiramos, con modestia más próxima, al Julián que conoció Guillén o a los escasos escultores de esta misma hora, huéspedes del barrio que subsiste contra el viento de la nueva población y cuyos formones han intimado con el perfil de las cabezas de San Juan y de San Luis y cuyos esmaltes cuidadosos saben de la receta antigua para el color ascético de la renuncia, para el violeta de la penitencia, para el encarnado de las llagaduras de Cristo y de las impresas en las manos y en los pies de San Francisco. El Santero don Julián. $Y$ luego, el apunte propio, el de la costumbre transmiticla con variaciones leves, como de cambios ligerisimos de indumentaria y que ahora serán tan reveladores de la vida de Arequipa como lo son algunos, todavía, de la ciudad de Quito, a pesar de la novísima existencia que se insinúa con la masticación de páginas extranjeras, pero que no consigue borrar absolutamente de las frentes nietas las imágenes heredadas de las abuelitas. Gesta nueva, diríamos, observando cómo se desenvuelve y corre, libre y alegre, el verso de Guillén en estos poemas de Arequipa. El mismo nos to había advertido, en alguno de sus pensamientos, de la tortura de la poesía, en la cárcel medida y dorada y musicada del verso. $Y$ no que falte aquí la gracia del ritmo, sin traba ni detención. Al contrario. El poeta liberado, aquel que viene de afuera para recogerse, sin angustia de elusiones, en su rincón de Arequipa, aquel que llega para un amor sin intercambio de dádivas, amor de conocimiento, 
expresa lo puro de la visión, lo nítido del encuentro, lo antiguo y reflotado en el recuerdo que se fuera para el campo de antes, en líneas que se tienden con su medida espontánea, en asonancias que no se calculan para ser encontradas.

Así escribieron todos los poetas y el mismo exámetro ilustre. no pudo salir absolutamente de un cálculo matemático. Nuevo verso libre el de Arequepay. Justo para esa modalidad que fuera llamada, por clasificadores actuales, nativista, terrenista, etc. ¿Pero qué se le da a Guillén el que se quiera definirle o determinarle? El ha sentido su Arequipa y asi nos la ofrece. Mañana, al amparo del incambiable Misti, ya no habrán santeros julianes y los abuelitos no llevarán quizá en el trac-trac de su cojear, el bastón con puño de calavera y un aro de oro con sus letras.

Pero el documento humano se ha formado en gracia de este madurar en niño que es típico florecer de Guillén, el buscador de sí mismo. No hay que pensar - magistralismos aparte- en que seremos actuales, novísimos, acordes con el ritmo contemporáneo, sólo cuando tengamos una memoria limitada al cuadro del presente. No hemos de vivir, es natural, como nuestros románticos bisabuelos que se prendieron en el ojal del levitón de paño resistente, la rosa castellanísima del siglo XIX ya mediado. Pero no por eso hemos de ignorar de dónde venimos. Bien está, por lo mismo, no sólo el tipo abuelario del Arequipa de Guillén, que es también tipo materno -releamos esa preciosidad de ternura filial, "Los capitanes de Salgari"-, sino también su encuentro con la momia de Pizarro y la poematización de la historia.

\section{El buscador de si mismo}

Alegría que no empece el dolor la de buscarse a sí mismo. Los caminos de la vocación conocen de aquélla y de éste. Porque no se trata, cuando una varonil templanza nos anima y nos sostiene, de rondar, con impaciencia avizora, sólo en pos de las agujillas de las cúpulas de la dicha. El encontrarse a sí mismo no es, en manera alguna, sólo un dichoso reconocerse. $\mathrm{Y}$ quien arriba en complacidas visiones, no puede ser en absoluto $y$ duradero caso, un vencedor. El buscarse a sí mismo implica un sabio desdén o una voluntad de 
graves superaciones que ya no ha de contar, para su pasajero contentamiento, no con las sonrisas de aprobación y acato que se manifiestan cuando nos piensan felices, aun cuando se oculte, en la ausencia de lo que los otros suponen copioso o pródigo en nuestra vida, el pesar que más nos sirve de acicate que de obstáculo y que cuandonos hiere acierta en la sangría para aligerarnos y elevarnos.

Aparte de las corrientes éticas que se referirían al libre arbitrio y a la fuerza del destino (el fatum de los griegos), plantearemos, por hoy, sólo el heroico rumbo de buscarse a sí mismo. Hay quien se halla de pronto en la calmosa temperancia de sus módulos biológicos y quizá se perfecciona después en el avance continuo y medido, en el contorno diario de sus formas espirituales, en el rebrillo de sus facetas, en la hermosa bondad de su fisonomía, en el resplandor de sus obras. Pero buscarse a sí mismo está en la lucha y en la superación. Lo disforme, lo imperfecto, lo brusco humanos, han de cambiarse, en combate continuo, como en el purgar contradictorio de la tragedia o han de caer, vencidos, cuando no puedan superarse a la forma con el impulso nuevo, cuando no consigan desarrollar en belleza, en verdad o en armonía, lo que fué turbulenta aspiración o desatinado amor. E1 genio helénico ya resolvió tan oscuro, tan enmarañado, $\tan$ hondo problema. Esquilo el viejo con el vencimiento de los dioses. Sófocles con el purgatorio de Antigona y Edipo. Eurípides con el grito herido del mundo. Lo cuerdo es detener la crítica frente a la locura de la hechicera Medea, sobre todo si no hemos escuchado a Jasón y si ya se apaga, en temblor cada vez más distante, el rumoreo de los coros. $Y$ otra vez volveremos a nuestro tema goethiano. No hay concierto entre el Werther que se destruye y el Fausto que dura. Disforme conciencia la del uno y saber de hondas raíces el del doctor de la alquimia y el cansancio. El joven Werther se buscaba sin encontrarse y aquél, hallándose, se perdía a veces, pero de su Walpurgis a su celeste diálogo hay el trecho que se marca, precisamente, entre el abandono de sí y la conquista de la serenidad. Sólo para el atediado de ayer florece, en verdad, con gracia plena, el laboratorio de la clausura, cárcel quizá para el alma inexperta, cuando no sea predestinada, y el agua muestra su frescor eterno y su diafanidad luciente cuando sirve para calmar una sed prolongada o cuando lava las heridas del caminante: 
E1 Alberto Guillén se acusa desde el comienzo el buscador de si mismo. A lo menos se manifiesta, con perfiles claros, en su modalidad literaria y bien sabido es que ésta constituye parte reveladora de la existencia. De niño ya se sentía con tal inquietud de viaje y de regreso. Nos lo dice, en frases líricas y sugeridoras, en sus "Capitanes de Salgari". Quería irse de si mismo y del corazón de su madre. No sabía qué desear. De grande sería sólo Capitán. No comería. Para enflaquecer. Para ver llorar a su mamá. ¿ Era tentación golosa de los labios de las mujeres? No tal en el Guillén niño. Sí. Sí. Eso, se dice rectificándose. Pero adviene el regreso filial. No se iría del corazón de su mamá ni de si mismo. Viajaría, es cierto, pero no para desgarrarse ni para mutilarse, pero no para aferrarse ni para quedarse. Dejaría algo de si, entero, fuerte, pero sin desintegrarse, sin aislarse de su propio centro. Asi ha resuelto el cuento que reconstruye, con tintas breves, de sus infantiles soñaciones tejidas entre las figuras que la mente va formando en las desigualdades de los cielos rasos de las casas antiguas, en las de las nubes y en el trayecto ilusionádo de los libros de estampas...

Se explora y explora. Por eso brotan sus cantos líricos. Los del Deucalión, los de la Imitación del Señor Yo. Por eso se trazan, con pluma de acero o con lápiz de viajante, sus observaciones de los seres y de las cosas y de las almas en El libro de las parábolas y en los Epigramas, y por eso, para darnos una visión de la realidad patria que fuera igualmente fértil para los niños y para los hombres, recrea en su último y pequeño grande libro, las figuras de Colón el Descubridor, de Pizarro el Conquistador y de Bolivar el Emancipador. La Historia es punto de referencia de los buscadores de si propios y cuando del poeta se trata, la historia poematizada adquiere rara vitalidad dranática y los hombres ya no se presentan en distancia mítica, porque perdida la nimia aridez detallista de sus hechos, el poeta suele ofrecernos la esencia de su obra. Asi en la vida de Colón, dándose a la platoniana insistencia de la redondez del mundo; Pizarro letrado, codicioso y sin acertar a leer Dios en la uña de Atahualpa y Bolivar, el máximo buscador y perdedor, sudoroso; " jadeante, sobre la mula más que viviente," saliendo de sus cansancios y de sus dolores, con la frase horadante y alta : vencer. $\mathrm{Y}$ así las Américas nuestras, descubiertas, conquistadas y emancipadas... pero no realizadas y cumplidas. 
Su "yo" actuante parece la inicial de su encuentro. Cuando enciende la lámpara diogenesca le vemos en la persecución de los otros. Pero su andanza no ha de prolongarse hasta el punto de que el observador se olvide de sí. Guillén rompe la lámpara, azoga nerviosamente el cristal para volverlo espejo y cuando descubre que la luciérnaga es un plagio de la estrella, bucea en la difícil estética de la originalidad. Sabe que sus parábolas serán redichas, conoce también un nuevo acento para rejtvenecerlas, pero no vacila en echar el grano, aun sin el reparo de que los surcos áridos no devuelvan en rama la piedad o el orgullo del sembrador.

No sabe morir en la vida, ni le han invadido, de seguro, aquellos amortecimientos de tenderse sin animación, como si nuestros ojos, ahitos de visiones o indignos de recogerlas nuevas, quisieran cerrarse obstinadamente, porque la entraña se siente como tun trapo de naufragio y está la frente tan llena de ceniza que ya no podrá recibir - inunca más ! - ni el beso de la que llegara para mirar en nuestros profundos milagros.

Para cada mañana el corazón fuerte y ágil el brazo.

De la emoción campera, sobre la esbelta mula peruana, a ras de la sierra del antiguo Eldorado, en carrera brava o distraída, a la línea azulosa del Pacífico -el barco que vuela siempre con ilusiones colónidas-, hacia Chile, hacia los jardines poéticos de Río y luego, por la ruta del Atlántico, hacia España, hacia el incrustamiento marino del Mediterráneo...

¿Por dónde se derrama el mar sin regreso? ¿Cuál la finitud de la tierra? Emprende en aquel viaje que saliendo de sí vuelve a si mismo y el labio untado de aires cosmopolitas, quiere modular las palabras niñas en el solariego recibimiento de Arequipa.

Hay que buscar, en realidad, el epicismo desparramado y extendido. Ver el Occidente. Sentirlo. Captarlo en el canto o en la nota que no dirá de nuestro oscuro vagar. Pero habremos también, y con derecho de entraña, de reavivar el cuadro que, de casi familiar, lo será también para la pequeñez o la grandeza de nuestra figura. Arequipa para Guillén.

El poeta está en sí, como lo estuvo ayer, viajero yoísta. Con su tema diogenesco, renovado, gusta de subir a su mirador de azulejos para ver pasar a los poetas de América. 
Su vista comparativa marcha, con la presteza de la metáfora, del hombre incano de la forja de Atahualpa, al que florece hoy, inquieto y amanecido, queriendo ser un buscador de si mismo.

\section{El árbol}

El Alberto Guillén de su ex-libris, quisiera adquirir la actitud centenaria del árbol. Así está la cabeza de tronco, ramificada. Pero no hay inmovilidad en su propósito arbóreo. No es el árbol transmutado en la columna. Ni el álamo tembloroso en la elegancia de una sola y rectilinea ascensión. Arbol humano, sensitivo, tremendo. En torno de su crecimiento, de su bullir incesante, de su retoño de constancia, pasan y pasan los hombres. Quisiera ser pararrayo y estancia de niños y de viajar una de sus ramas en la velocidad de la piragua, no se olvidaría de que alli, sobre la tierra unánime, late el yigor troncal, devolviéndose en el lustre de las hojas renovadas y elaborando, para ascender y frutecer, la savia que es.licor de vitalizaciones. Mójale la lluvia, ilumínale el rayo en la resina espejeante, báñale de claridades el sol andino, y él resume, de las fuerzas que le abrasan y que le bañan, la parábola de su perduración. No. No ha de morir el árbol cabeza. Se ha sembrado para viajar. Hará viajes innumerables. El fruto es nutrición y reverdecimiento. Ayer la flor. La madera grita con el hacha tajante y dura en el júbilo de sus resistencias. Retablo o bargueño. Nave o lecho. Ataúd...

$\mathrm{El}$ árbol viajero que parecía sembrado. El árbol cabeza de cabellos vegetales. De ojos múltiples reventados en las flores. De oídos que se abren más generosamente al mundo en las grietas de la corteza. El árbol millonario de filtros. Trepado de néctares. Atormentado y sublimado de estremecimientos.

Viajeros somos, viajeros desterrados sobre la tierra. No hemos de llegar nunca. Acicatéanos la prisa de seguir, el anhelo de ver. Pero a poco trecho - a mucho tal vez-, el confin es más confin y. la distancia más distancia. Somos tan poca cifra para la inquietud que llevamos dentro. ¿ Por qué no, Alberto Guillén, por quẻ no hemos de retener en la pupila de una sola mañana de una existencia tan dilatada, todos, pero todos los paisajes que nos obseden? ¿ Por qué no hemos de besar, Alberto Guillén, con los labios que serán 
los pétalos de una sola, pero de una sola de las flores de la vida, los labios de las mujeres que amamos?

Viájeros somos, viajeros con la tentación en cada día más a flor de la dicha colmada. Esta no es nuestra ciudad, ni la otra. También el árbol da de sí y recibe. ¿ No será ésta o aquélla su tierra, no será éste su bosque, no será aquél su jardín? No sabemos si el árbol quisiera desprenderse de las raíces que viajan soterradas y partir... Pero al árbol no le sigue su sombra, ni se desparrama y multiplica en las ramas anhelantes del hombre, ni tiene, como éste, el fruto ávido de reventar.

$\mathrm{Al}$ árbol volveremos. Al fin, nuestra devolución física se trepará por làs ramas de un sauce.

¿Volveremos a la columna, Alberto Guillén? Cttando tú estés silencioso, cuando yo esté silencioso, cerca de la columna vertical o que ascienda en espira, como la de la aspiración, revolará nueva colmena indiferente. Los hombres, más que los de hoy, se afilarán en su guerra contra las columnas y contra los símbolos, dispararán flechas envenenadas contra los árboles ajenos... Y después, es posible, plantarán un árbol y la violación del viento, más tarde, soplará en su cabellera hojosa sobre los pensamientos que florezcan. $\mathrm{Y}$ una loca revolución de pájaros cantará de nuevo su masculino temblor sobre la piedad femenina de las hojas.

¿Para qué un ex-libris de corazón aislado sobre devocionario romántico? ¿ Para qué el vagar de la pluma sola y alta y regresadora en su descenso? ¿Para qué la copa de cuasia abandonada a la sed con su destino de amargar los labios?

El árbol, sostenido de raíces, en la entraña de la tierra, con orígenes vitales y prolongaciones vitalizadoras. $\mathrm{El}$ árbol de crecimiento y de longevidad, el árbol sensitivo y eterno, casi eterno.

\section{Viajero sin viaje}

Llegaba yo, tras de una jornada violenta. $\mathrm{Y}$ el desfile de la cadena de sepia de la cordillera y el huir de la serpiente polvorosa del camino que ibase tragando las ciudades minúsculas y las aldehuelas perdidas... Aquí el amor mugiente de la vacada. Alli el vellón apretujado del rebaño. $Y$ en el páramo seco, quemado, eri- 
zado de manchăs espinosas, casi a nivel de las estribaciones volcánicas, la cierva huyente, con sus cuernos casi vegetales, casi de rama y su esquividad de doncella... Aquí la pluma frustrada de los sigsis, allá la espada flexible de la espadaña. La nota igual de los alfalfares y los dibujos de la huerta, más adentro... Y escondida, como para recoger en nota de inteligencia y sobriedad todos los rumores del camino, para elevarlos al logaritmo de un solo pensamiento, o de dos si queréis, la casa de hacienda con sus tibiezas de hogar y sus levedades de nido... Pero algo habiame dicho que al cabo de la ausencia y del silencio de interregno, habríanse cambiado las decoraciones en otro tiempo conocidas y que los oídos acogedores de la estancia habrían borrado el eco de las palabras de otra mañana. $\mathrm{Y}$ nada, nada de ayer. Sólo la línea que se traza sin rumbo y que se proyecta en las adivinaciones de los que nos hemos quedado o de los que llegamos.

Pero en medio del patio cuadrangular, ahora desolado, alzábase el pino que con su vigilante bullir había celebrado mis audacias más alegres. Arbol erguido, sin errabundeces y sin congojas. Arbol fuerte que sabía estar con su recuerdo sereno en la casa entonces inhóspita. No quería buscar huellas difíciles y en su filosofía vertical recogería tan sólo el rumor de los pasos circundantes.

... Este es aquél que regresa por la vida ancha y cuyo espíritu se aprieta por una sola viajera. Así la frase del árbol serenado.

Ramas inquietas, Alberto Guillén, las de nuestros árboles. Ramas quebradizas. Y cuando damos el fruto apénanse los árboles estériles por la sapidez que pusimos en la poma y si nos elevamos en la fortaleza de crecer, los matorrales del páramo concitan a los vientos y convocan a las heladas para que dirijan contra nuestro follaje sus cuchillas asesinas.

Arboles viajeros y combatidos acaso. Pero, ¿ por qué no desear para la vida del arte y para la vida de la vida, el símbolo de perduración del árbol?

Arbol, Libro e Hijo. Alberto Guillén, trino y uno. Brazos de rama. Su raíz ya no puede ser removida por el terremoto.

Augusto Arras 
